\title{
ISOLATION OF HUMAN CHROMOSOME 21-SPECIFIC COSMIDS AND THEIR USES IN MAPPING OF COSMID CONTIGS ON CHROMOSOMAL SUBREGIONS
}

\author{
De-Xing Hou,* Haruo Kishida, Takanori Shimokawa, \\ and Eiichi SoEDA \\ Gene Bank, Tsukuba Life Science Center, The Institute of Physical and Chemical Research \\ (RIKEN), 3-1-1 Koyadai, Tsukuba, Ibaraki 305, Japan
}

\begin{abstract}
Summary A cosmid library of $3 \times 10^{5}$ clones has been constructed from a human $\times$ hamster hybrid cell line, $153 \mathrm{E} 9 \mathrm{a} 3$, which contains human chromosome $21(\mathrm{HC} 21)$ as the only human chromosome. From 56,500 clones of this library, $229 \mathrm{HC} 21$-specific cosmids have been isolated by their hybridization to total human DNA and by their failure to hybridize to total Chinese hamster DNA. The cosmids isolated were then characterized, of these, 28 cosmids (12.2\% of those tested) contained Not 1 site(s), and 41 cosmids were localized on the eight subregions of HC21 by differential hybridization with $A l u$-PCR products obtained from a hybrid mapping panel. The cosmids localized were further integrated into the existing contigs using the end-specific probes of the clone insert. Therefore, they provided useful anchor points for contig mapping and walking.

Key Words human chromosome 21, cosmid library, cosmid contig, regional mapping
\end{abstract}

\section{INTRODUCTION}

Human chromosome 21 (HC21) represents a model for physical mapping of the human genome because it is the smallest human autosome and associates with several genetic diseases, including Down's syndrome, some forms of Alzheimer's disease and other neurological diseases (Stewart et al., 1989). The cloning and regional mapping of chromosomal DNA will speed the characterization of the disease-related genes. Recently, a continuous unit of yeast artificial chromosomes (YACs) covering the entire human chromosome $21 \mathrm{q}$ has been constructed using

Received August 24, 1994; Revised version accepted October 4, 1994.

* To whom correspondence should be addressed. 
sequence-tagged sites (STS) as landmarks (Chumakov et al., 1992a). YACs provide an efficient way to order large genomic regions but they tend to have high frequency of chimerism, deletions and rearrangements (Schlessinger, 1990; Christopher, 1993). Unlike YACs, cosmids tend to have more stable inserts with little chimerism. Such cosmid contig maps will provide easily accessible materials for determining genome organization and for obtaining the DNA sequence.

For these reasons, we have begun to construct the HC21 contig map with cosmid clones. Our project consisted of two logical steps: first, the cosmid clones from a primary library were assembled into sets of overlapping cosmids (contigs) based on the fingerprinting method (Carrano et al., 1989); second, contigs were mapped onto HC21 with known markers, and the gaps between contigs were closed up by other cosmid clones. To date, we have fingerprinted approximately 9,300 cosmid clones from a HC21 fiow-sorted linrary (constructed in Lawrence Livermore National Laboratory) by automated fluorescence-based fingerprinting method (Carrano et al., 1989), and assembled 4,440 cosmids of them into 467 contigs by a computer algorithm on the basis of measured overlap probability (the log likelihood ratio) statistics that exceeded an acceptable threshold (Branscomb et al., 1990) (submitted for publication). Now, we are mapping these contigs onto HC21 and trying to close the gaps between the contigs. However, we have noted that some gaps, where no junction clone exists in this library, must be closed with other libraries.

Here, we constructed a cosmid library from a human $\times$ hamster hybrid cell, 153E9a3, which retains $\mathrm{HC} 21$ as the only human chromosome. The $\mathrm{HC} 21$-specific cosmids were isolated from this library and then localized on HC21 subregions. The cosmids localized were further used to map the existing contigs and to close the gaps between contigs.

\section{MATERIALS AND METHODS}

Library construction. The human $\times$ hamster hybrid cell line 153E9a3, which retains human chromosome 21 as the only human chromosome (Patterson et al., 1985), was used as the cloning source. The cell was cultured in F12 medium with $10 \%$ fetal bovine serum. The unique presence of human chromosome 21 was certified by fluorescence in situ hybridization (Hou, unpublished data). Highmolecular-weight DNA was extracted and partially digested by Sau3AI according to standard method (Maniatis et al., 1989). Fragments between 35 and $50 \mathrm{~kb}$ were collected by sedimentation through a sucrose density gradient and then dephosphorylated. A high efficiency cosmid vector, sCos-1 (Evans et al., 1989), was prepared by $X b a I$ digestion and dephosphorylation. After the cloning site was cleaved with BamHI, the vector DNA was ligated with dephosphorylated insert DNA and then packaged using the Gigapack Gold System (Stratagene). Finally, the assembled particles were transfected into E. coli 490A (Stelnmetz et al., 1982) 
and plated under ampicillin selection. This library has been designated as RL01. Identification of human cosmid clones. The cosmid clones were plated at a density of $1,000-2,000$ clones per $150-\mathrm{mm}$ plate and then transferred to nylon membranes. The human placental DNA (Sigma) was labeled with $\left[\alpha^{-32} \mathrm{P}\right] \mathrm{dCTP}$ by the random primer labeling method (Feinberg and Vogelstein, 1983) and hybridized to the filters according to standard methods (Maniatis et al., 1989). The positive clones were picked and transferred into individual wells of microtiter plates. After overnight culture, two replica filters were made using a 96-needle transferring device. One filter was hybridized with labeled human DNA and the another was hybridized with labeled hamster DNA. The clones that hybridized to human DNA with no detectable signal to hamster DNA were transferred into individual wells of microtiter plates, grown overnight, and then frozen at $-80^{\circ} \mathrm{C}$ in LB media plus $20 \%$ glycerol and $100 \mu \mathrm{g} / \mathrm{ml}$ ampicillin.

Hybrid mapping panel of chromosome 21. Figure 1 presents a diagram of the hybrid mapping panel. The following seven cell hybrids, containing partial chromosome 21 and dividing the chromosome 21 into eight regions, were used as template

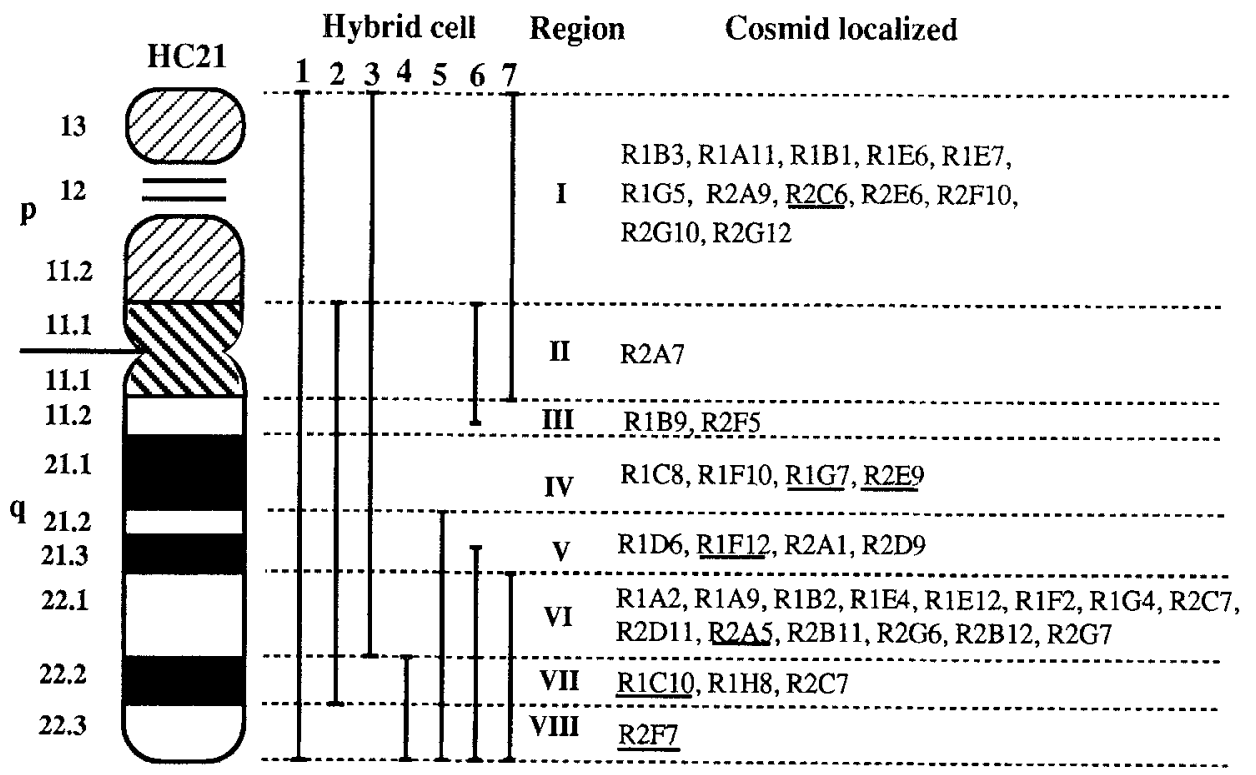

Fig. 1. Regional mapping of human chromosome 21-specific cosmids. (Left) Schenatic representation of the human chromosome 21 contents of the cell hybrids. The vertical lines indicate the portion of chromosome 21 presents in each hybrid. The cell hybrids divide the chromosome 21 into eight subregions. 1, 153E9a3; 2, R2-10W; 3, 21q ; 4, 8q-a ; 5, 1881C-13b: 6, ACEM2-10d; 7, JC-6A. (Right) A total of 41 cosmids was localized in the eight subregions of chromosome 21 by differential hybridization of 229 cosmid clones with Alu-PCR products obtained from seven hybrid cells. The cosmid with an underline indicates that it contains Not I site. 
DNAs for Alu-PCR amplification: 153E9a3, R2-10W (containing 21p11.1-q22.2),

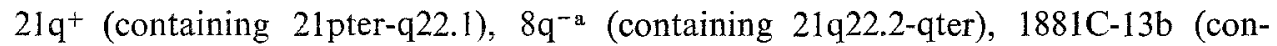
taining 21q21.2-qter), ACEM (containing 21cen-q11.1 and q21.3-qter), and JC-6A (containing 21pter-q11.1 and 21q21.3-qter). Detailed analyses of these hybrids have been described elsewhere (Patterson et al., 1985; Gardiner et al., 1990).

Alu polymerase chain reaction (Alu-PCR). An Alu-primer 3144 (Monaco et al., 1991) was used to amplify human DNA sequences from seven cell hybrids (Fig. 1). It was synthesized on an Applied Biosystems 380B DNA synthesizer and subsequently purified by OPC column. The PCR reaction was performed on a GeneAmp PCR System 9600 (Perkin Elmer Cetus). The PCR reaction mixture contained $1 \mu \mathrm{g}$ of each cell hybrid DNA and $1.25 \mu \mathrm{M}$ of the Alu primer in $100 \mu \mathrm{l}$ of $0.01 \mathrm{M}$ Tris- $\mathrm{HCl}(\mathrm{pH} 8.3), 0.0015 \mathrm{M} \mathrm{MgCl}_{2}, 0.05 \mathrm{M} \mathrm{KCl}, 250 \mu \mathrm{M}$ of each dNTPs, and 2.5 units of Cetus Taq polymerase. The template DNAs were initially denatured at $94^{\circ} \mathrm{C}$ for $2 \mathrm{~min}, 45$ cycles of PCR were then performed, each cycle consisting of a $2-\mathrm{min}$ denaturation at $94^{\circ} \mathrm{C}$, a 2 -min annealing at $57^{\circ} \mathrm{C}$, and 4 -min extension at $74^{\circ} \mathrm{C}$. The final extension was carried out at $74^{\circ} \mathrm{C}$ for $10 \mathrm{~min}$. The PCR products were analyzed by electrophoresis on a $1.2 \%$ agarose gel. The remainder was used as a probe after it was extracted with phenol-chloroform.

Differential hybridization. A method based on the differential hybridization of cosmid clones with amplified inter- $A l u$ sequences from a set of somatic cell hybrids was used to localize the cosmids onto subchromosomal regions (Zucman et al., 1992). The HC21-specific cosmid clones were spotted onto nylon membrane using a robotic device (Biomech 1000 , Beckman), and grown at $37^{\circ} \mathrm{C}$ for overnight. The filters were baked and prehybridized for $2 \mathrm{~h}$ at $72^{\circ} \mathrm{C}$ in the hybridization solution of $1 \mathrm{M} \mathrm{NaCl}, 50 \mathrm{~mm}$ Tris- $\mathrm{HCl}(\mathrm{pH} 8.0), 5 \mathrm{~mm}$ EDTA, $1 \%$ SDS, $10 \%$ dextran sulphate, and $200 \mu \mathrm{g} / \mathrm{ml}$ sonicated human placental DNA (Sigma). One hundred nanogram PCR product from each cell hybrid was labeled by the random primer labeling method, and purified through Sephadex G-50. One hundred nanogram of the labeled DNA and $40 \mu \mathrm{g}$ of human placental DNA in $400 \mu \mathrm{l}$ of $0.5 \times$ hybridization solution (final) were denatured at $95^{\circ} \mathrm{C}$ for $7 \mathrm{~min}$, and then incubated at $72^{\circ} \mathrm{C}$ for $2 \mathrm{~h}$. After suppression, the probe DNA was added to the hybridization bag, and hybridized for $14 \mathrm{~h}$ at $72^{\circ} \mathrm{C}$ (Chumakov et al., 1992b). The filters were washed with $2 \times \mathrm{SSC}$ at room temperature for $15 \mathrm{~min}$, and with $0.1 \times \mathrm{SSC}, 0.1 \% \mathrm{SDS}$ at $65^{\circ} \mathrm{C}$ for $30 \mathrm{~min}$. The autoradiography was done for $24-36 \mathrm{~h}$ at $-80^{\circ} \mathrm{C}$ with one intensifying screen.

Linear PCR. Linear PCR for creating end-specific probes of the clone insert was prepared by two independent reactions, using $\mathrm{T} 3$ and $\mathrm{T} 7$ primers, which correspond to the T3 and T7 promoter sequences adjacent to the cloning site of the vector (Caerano-Anollies et al., 1991). The EcoRI-digested cosmid DNA was purified through phenol-chloroform extraction and then used as a template in linear PCR with [ $\alpha^{32}$ P]dCTP (Mizukami et al., 1993). The PCR was done with 30 cycles, each cycle consisting of 1 -min denaturation at $94^{\circ} \mathrm{C}, 1.5-\mathrm{min}$ annealing at $53^{\circ} \mathrm{C}$, 
and 1-min extension at $74^{\circ} \mathrm{C}$. The linear PCR products were directly hybridized to the arrayed cosmid filters according to the method as described previously (Mizukami et al., 1993).

\section{RESULTS}

\section{Library composition}

A cosmid library containing $3 \times 10^{5}$ clones was constructed from the cell hybrid, $153 \mathrm{E} 9 \mathrm{a} 3$, which contains human chromosome 21 as the only human chromosome. Of the library, 56,500 clones have been screened and the library composition was shown in Table 1. The result of the first screening with labeled human DNA indicate that $0.4 \%$ clones of the library showed positive signals to human DNA probe. The 282 clones obtained from the first screening were further hybridized to labeled human DNA and hamster DNA, respectively. Of which, 229 clones $(81.2 \%)$ hybridized to human DNA, 24 clones $(8.5 \%)$ to hamster DNA, 15 clones $(5.3 \%)$ to both, and 14 clones $(5.0 \%)$ to neither. The insert size of the cosmid clones was estimated as $38 \pm 8 \mathrm{~kb}$ by digesting 10 cosmids with EcoRI endonuclease.

\section{Testing cosmids for NotI restriction site}

To investigate the presence of NotI site of the cosmid clones, 229 of HC21-specific cosmids were digested with five units of Not I endonuclease per microgram of DNA under the conditions recommended by the manufacturer, and then fractionated by electrophoresis in a $1 \%$ agarose gel. Since the vector, sCos-1, contains two Not I sites, more than two bands would be detected if the insert DNA contains Not I site. We found a total of 28 cosmids $(12.2 \%$ of those tested) contained one or two NotI sites.

\section{Chromosomal mapping of the cosmids}

Human DNA sequences from somatic cell hybrids were amplified with the Alu primer 3144. The total complexity of the Alu-PCR products appears to correlate with that of the human contents of the respective hybrids, and no amplification product was detected in hamster DNA (data not shown). Each Alu-PCR product obtained from seven cell hybrids was labeled and hybridized to the replica filters of the arrayed HC21 cosmid clones with total human DNA suppression. Figure

Table 1. Assessment of library composition by species-specific colony hybridization.

\begin{tabular}{|c|c|c|c|c|}
\hline \multirow{2}{*}{$\frac{\text { Screening }}{\text { First screening }}$} & \multirow{2}{*}{$\frac{\text { Clones }}{70,500}$} & \multicolumn{2}{|l|}{ Positive clones } & \multirow{2}{*}{$\frac{\text { Percentage }}{0.40 \%}$} \\
\hline & & human & 282 & \\
\hline \multirow[t]{4}{*}{ Second screening } & 282 & human & 229 & $81.2 \%$ \\
\hline & & hamster & 24 & $8.5 \%$ \\
\hline & & buman + hamster & 15 & $5.3 \%$ \\
\hline & & no signal & 14 & $5.0 \%$ \\
\hline
\end{tabular}




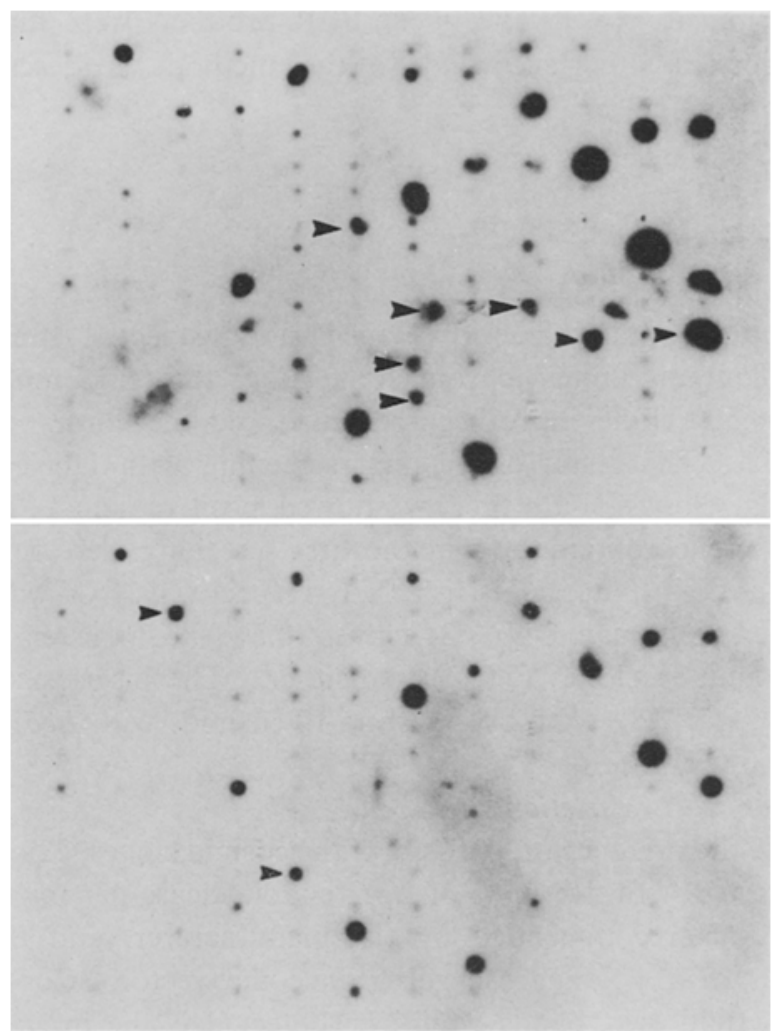

Fig. 2. Differential hybridization signals obtained when the Alu-PCR products from the cell hybrids R2-10W (upper) and JC-6A (lower) were hybridized to the same filter of cosmid clones. The positive clones are observed on the autoradiogram. Arrows indicate the cosmid clones showing obvious differential hybridization signals for the two probes.

2 shows the representative differential hybridization signals of cosmid clones to the Alu-PCR products obtained from cell hybrids, R2-10W and JC-6A. Using clear-cut stringent criteria for analysis of differential hybridization (Zucman et al., 1992), essentially the positive signal cosmid could be unambiguously grouped in one of eight different regions according to its pattern of hybridization. This analysis identified 41 cosmids potentially located in the eight different regions of chromosome 21 (Fig. 1). Ten cosmids did not meet the clear-cut stringent criteria, and they were not further analyzed. To estimate the targeting efficiency of this method, we used a YAC clone, SOD1 that has been localized on 21q22.1 (region VI) (Imai et al., 1990), as probe to screen the arrayed cosmid filters. Four positive clones (R1A9, R1B2, R1E4, and R1G4) that were potentially localized on region VI (Fig. 1) were obtained. Furthermore, DNA from these four cosmids was used for in situ hybridization to normal human metaphase, and a pair of strong signals 


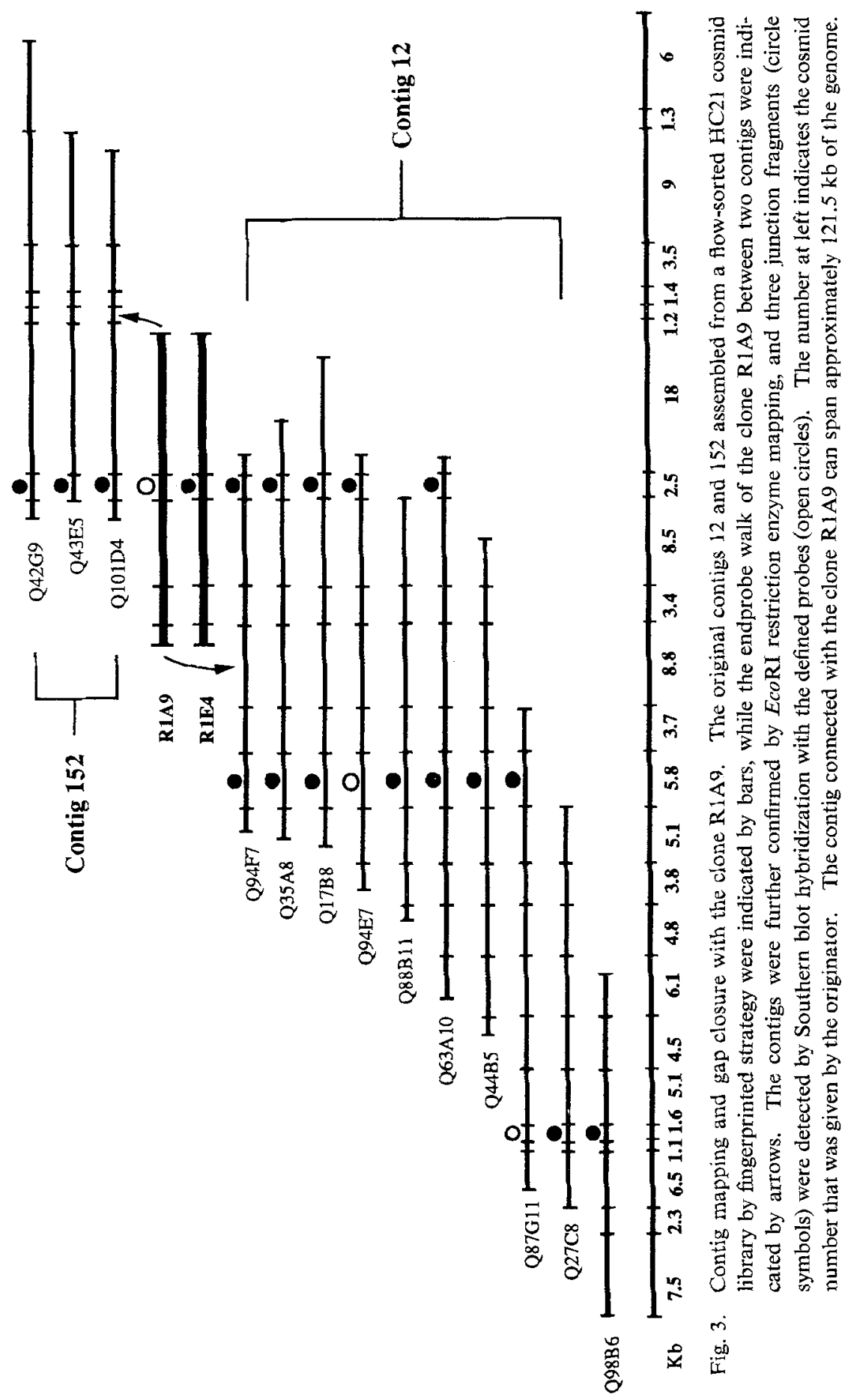


without background were observed in the region VI (data not shown).

\section{Anchoring cosmid contigs onto chromosome 21 using the mapped cosmids}

The end-specific probe of clone localized was generated by the inward-facing T3 or T7 promoter located at the clone site of the vector, and then hybridized to the arrayed cosmid filters. A typical example is shown in Fig. 3, the T3 and T7 end probes from the clone R1A9, that has been localized on region VI (21q22.1) by $A l u$-PCR method, was used to screen the arrayed cosmid clones from Livermore's library and our library. The T3-end probe hybridized to seven clones (Q94F7, Q35A8, Q17B8, Q94E7, Q88B11, Q63A10, and Q44B5) in existing contig 12, the T7-end probe hybridized to all of three clones in existing contig 152, and both of probes hybridized to the clone R1E4 that was a similar clone to R1A9. To define the overlap relationship between the clone R1A9 and two contigs, all of clones were digested with EcoRl, and then analyzed by Southern hybridization. The junction fragments were also detected on autoradiograms as unique fragments by using overlapping fragments as probes (Fig. 3). The results indicate that the gap between contigs 12 and 152, where no junction clone exists in the original library, can be closed up with the clone R1A9 and both contigs were mapped onto the region VI (2lq22.1) of HC21. The localization of the contig 152 was also confirmed by PCR-specific detection of these clones with the primer $93 \mathrm{~B} 1012$ that is a STS landmark localized at 21q22.1 (Hou et al., unpublished data).

\section{DISCUSSION}

We have begun to construct the HC21 contig maps with cosmid clones. As a complementary step of this project, we have constructed a cosmid library from a human $\times$ hamster hybrid cell, 153E9a3, which contains $\mathrm{HC} 21$ as the only human chromosome. To map the cosmid clones onto chromosomal subregions rapidly, we carried out differential hybridization of the HC21-specific cosmid clones with amplified inter- $A l u$ sequences obtained from somatic cell hybrids. Of these, 41 cosmids have been localized in eight subregions of HC21. The targeting efficiency of this method was evaluated by YAC-cosmid hybridization and in situ hybridization. The map location of cosmids derived by these methods showed excellent correspondence.

We have further identified 28 cosmids ( $12.2 \%$ of those tested) that contained one or two NotI sites. NotI site is present, as rare restriction site, in vertebrate genome and its distribution is related to the distributions of genes (Bird, 1986). It has been reported that $9.4 \%$ of chromosome 3 -specific cosmids carried one or two Not I sites and they contained gene sequences (Golembieski et al., 1991). Our cosmids also carried NotI site with similar ratio. These cosmids should be a valuable resource for the identification of chromosome 21 -specific genes.

Finally, we used these localized clones to anchor our existing contigs on HC21 
and to close the gaps between the contigs. Of course, we can also do these works by the fingerprinting method. But, we have noted that the fingerprinting method tends to assemble the additional, redundant clones into existing contigs, instead of covering gaps. To discover the small overlaps between clones, we used endspecific probes of a clone insert, made available by the inward-facing T3 and T7 promoters located at the cloning site of the cosmid vector. Our results indicate that some contigs can be anchored onto $\mathrm{HC} 21$ and some gaps between contigs can be effectively closed up with the end-specific probes of these cosmids localized. Thus, these cosmids provided useful anchor points for contig mapping and walking. Of course, we also recognized that all of gaps between 4,440 contigs are difficult to be closed up with our 229 cosmids. The final closure of these gaps still needs other cosmids or YAC clones. The works of contig anchoring and gap closure are in progress, the final results will be summarized in another paper.

Acknowledgments We thank Dr. David Patterson for kindly providing the hybrid cell lines, and Dr. Katy Walton for shipping all the cell lines. We also thank Mr. Kazuo Ozawa for technical help in the initial stage of the cosmid library construction. This work was supported by the human genome research program of RIKEN and the Science and Technology Agency of Japan.

\section{REFERENCES}

Bird AP (1986): CpG-rich islands and the function of DNA methylation. Nature 321: 209-213

Branscomb E, Slezak T, Pae R, Galas D, Carrano AV, Waterman M (1990): Optimizing restriction fragment fingerprinting methods for ordering large genomic libraries. Genomics 8, 351366

Caerano-Anollis G, Bassam BJ, Gresshoff PM (1991): DNA amplification fingerprinting using very short arbitrary oligonucleotide primers. Biotechnology 9: 553-557

Carrano AV, Lamerdin J, Ashworth LK, Watkins B, Branscomb E, Slezak T, Raff M, deJong PJ, Keith D, McBride L, Meister S, Kronick M (1989): A high-resolution fluorescence-based, semiautomated method for DNA fingerprinting. Genomics 8: 129-136

Christopher A (1993): Genome shortcut leads to problems. Science 259: 1684-1687

Chumakov I, LeGall I, Billaut A, Ougen P, Soularue P, Guillou S, Regault P, Bui H, De Tend MK, Barillot E, Abderrahim H, Cherif D, Berger R, LePaslier D, Cohen D (1992a): Isolation of chromosome 21-specific yeast artificial chromosomes from a total human genome library. Nature Genet 1: 222-225

Chumakov I, Regault P, Guillou S, Ougen P, Billaut A, Guasconi G, Gervy P, LeGall I, Soularue P, Grinas L, Bougueleret L, Bellanné-Chantelot C, Lacroix B, Barillot E, Gesnouin P, Pook S, Vaysseix G, Frelat G, Schmitz A, Sambucy JL, Bosch A, Estivill X, Weissenbach J, Vignal A, Riethman H, Cox D, Patterson D, Gardiner K, Hattori M, Sakaki Y, Ichikawa H, Ohkj M, Paslier DL, Heilig R, Antonarakis S, Cohen D (1992b): Continuum of overlapping clones spanning the entire human chromosome $21 \mathrm{~g}$. Nature 359: 380-387

Evans GA, Lewis K, Rothenberg BE (1989): High efficiency vectors for cosmid microcloning and genomic analysis. Gene 79: 9-20

Feinberg AP, Vogelstein B (1983): A technique for radiolabeling DNA restriction endonuclease fragments to high specific activity. Anal Biochem 132: 6-13

Gardiner K, Horisberger M, Kraus J, Tantravahi U, Korenberg J, Rao V, Reddy S (1990): Analysis of human chromosome 21 : correlation of physical and cytogenetic maps: gene and CpG 
island distribution. EMBO J $9: 25-34$

Golembieski WA, Smith SE, Recchia F, Judge A, Shridhar V, Miller OJ, Drabkin H, Smith DJ (1991): Isolation of large numbers of chromosome 3-specific cosmids containing clusters of rare restriction-endonuclease sites. Am J Hum Genet 49: 581-589

Imai T, Iida A, Miwa T, Tashiro H, Song T-C, Yokoyama K, Soeda E (1990): Analysis of YAC clones by Pulsed-field gel electrophoresis: Physical mapping of $\mathrm{Cu} / \mathrm{Zn}$ superoxide dismutase gene locus. Methods: A Companion to Methods in Enzymology 1: 180-185

Maniatis T, Fritsch EF, Sambrook J (1989): Molecular cloning. A Laboratory Manual (2nd ed), Cold Spring Harbor Laboratory, Cold Spring Harbor, New York

Mizukami T, Chang WI, Kaplan N, Lombardi D, Matsumoto T, Niwa O, Kounosu A, Yanagida M, Marr TG, Beach D (1993): A $13 \mathrm{~kb}$ restriction cosmid map of the $14 \mathrm{Mb}$ fission yeast genome by nonrandom sequence-tagged site mapping. Cell 73: 121-132

Monaco AP, Lam VMS, Zehetner G, Lennon GG, Douglas C, Nizetic D, Goodfellow PN, Lehrach $\mathrm{H}$ (1991): Mapping irradiation hybrids to cosmid and yeast artificial chromosome libraries by direct hybridization of $A l u$-PCR products. Nucleic Acids Res 19: 3315-3318

Patterson D, Van Keuren M, Drabkin H, Watkins P, Gusella JF, Scoggin C (1985): Molecular analysis of chromosome 21 using somatic cell hybrids. Ann NY Acad Sci 450: 109-120

Schlessinger D (1990): Yeast artificial chromosomes: toos for mapping and analysis of complex genomes. Trends Genet 6: 248 -258

Stelnmetz M, Winoto A, Minard K, Hood L (1982): Clusters of genes encoding mouse transplantation antigens. Cell $28: 489-498$

Stewart GD, Van Keuren ML, Galt J, Kurachi S, Buraczynska ML (1989): Molecular structure of human chromosome 21. Annu Rev Genet 23: 409-423

Zucman J, Delatter O, Desmaze C, Azambuja C, Rouleau G, Jong PD, Aurias A, Thomas G (1992): Rapid isolation of cosmids from defined subregions by differential Alu-PCR hybridization on chromosome 22-specific library. Genomics 13: 395-401 